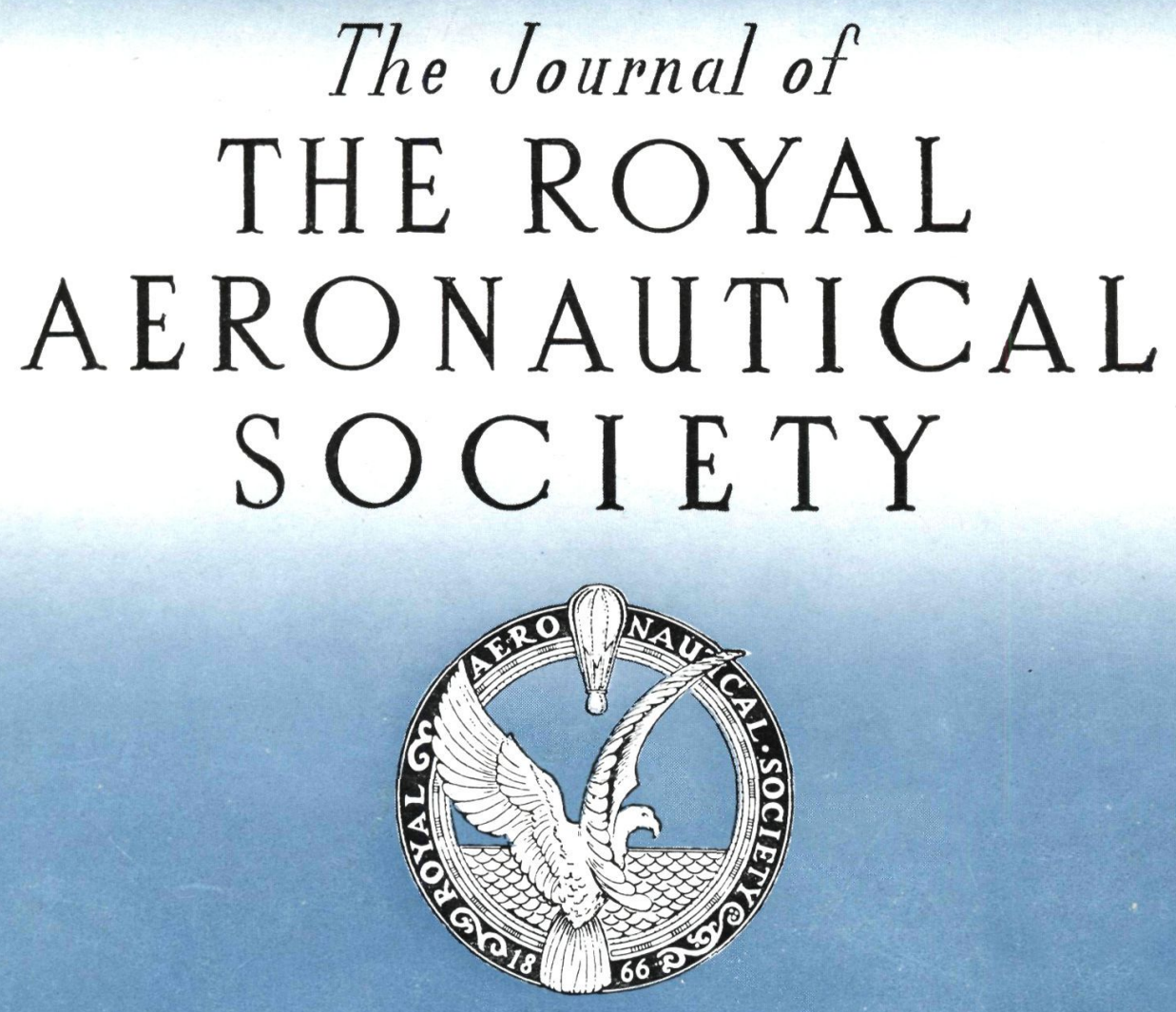

CONTENTS

MAY 1951

X POWER VERSUS WEIGHT IN AVIATION

MAURICE ROY

$X$ BOUNDARY LAYERS AND SKIN FRICTION IN HIGH-SPEED FLOW

A. D. YOUNG, M.A., F.R.Ae.S.

X PLANNING AND AIRCRAFT DEVELOPMENT

F. OLAF THORNTON, A.F.R.AE.S.

\title{
LONDON
}

ROYAL AERONAUTICAL SOCIETY, 4 HAMILTON PLACE, W.1 


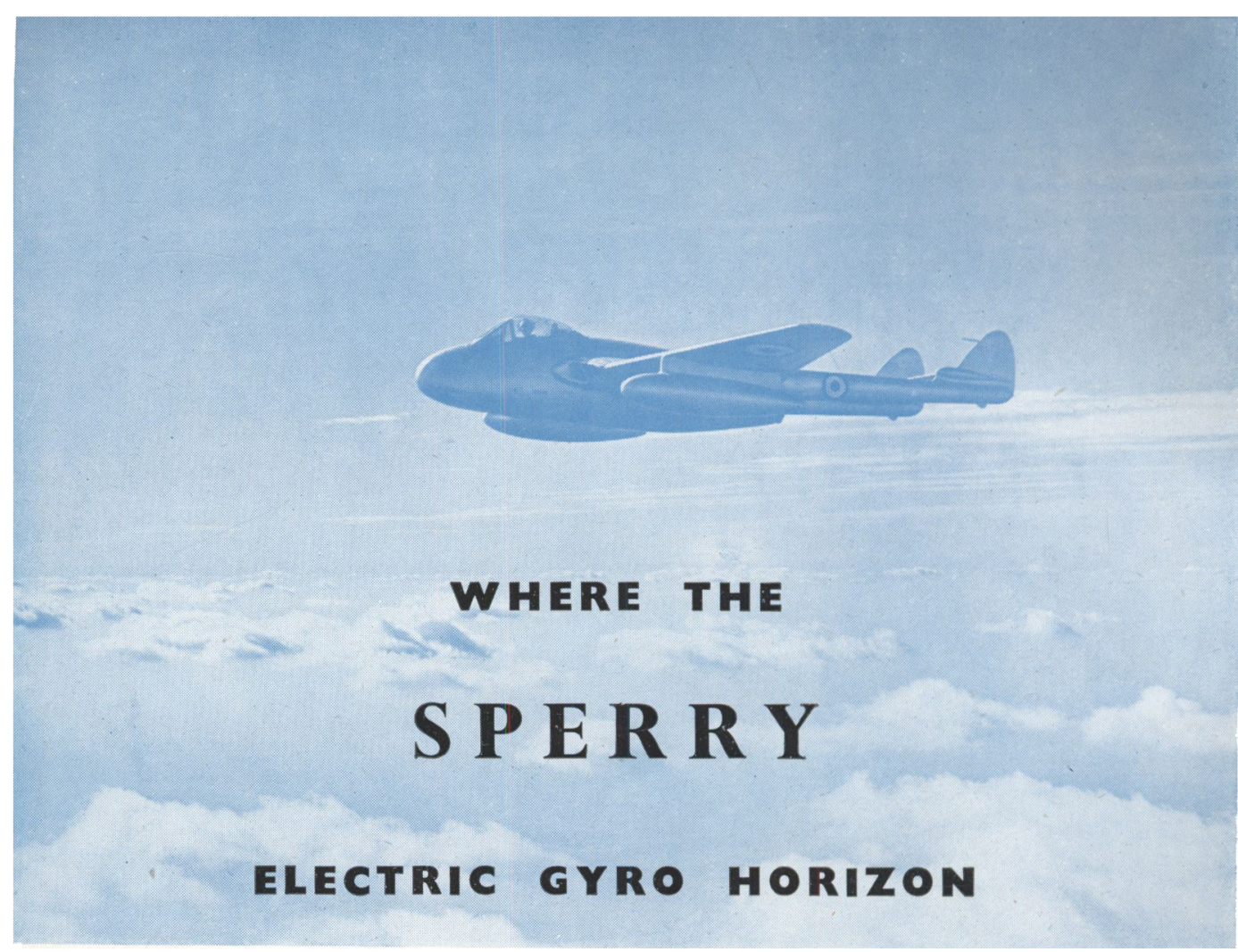

\section{IS SUPREME}

High-speed jet combat aircraft are called upon to operate under a variety of conditions and the Sperry Electric Gyro Horizon is used constantly as an accurate attitude reference, its topple-free design making it eminently suitable. At high altitudes its electrical operation ensures that it remains fully effective and reliable.

Extensive Service trials have proved again the high quality of Sperry instruments and this Horizon is now being specified by the R.A.F. for its latest designs of jet aircraft.

Modern combat machines are called upon to fly at altitudes where the low atmospheric pressure precludes the use of vacuum-operated instruments as these become inaccurate and unreliable.
Similarly the air-driven Directional Gyros in jet aircraft are now superseded by the Sperry Gyro Magnetic Compasses, Mark 4 Series.

The Sperry Electric Gyro Horizon Type H.L.5 (Mk. 3) has complete freedom in roll throughout $360^{\circ}-$ i.e., it is topple-free -and it will register $80^{\circ}$ of climb or dive.

It is not affected by low outside temperatures.

It has a rotor that runs almost twice as fast as that of an airdriven instrument and its performance is correspondingly better. It is free from air-filtration troubles.

There is no obstruction of horizon presentation by the front bearing support.

It is fully stressed for jet fighter operation.

It is easy to install and maintain. Power supply : 115-volt, 400-cycle, 3-phase A.C., or through an inverter connected to the normal 12 or 24 -volt D.C. Supply.

It fits the standard instrument panel cut-out and thus can directly replace the air-driven Horizon.

\section{S P E R R Y}

ELECTRIC GYROHORIZON

THE SPERRY GYROSCOPE COMPANY LTD., GREAT WEST ROAD, BRENTFORD, MIDDLESEX. PHONE: EALING 6771 


\section{H A W K E R}

\section{S I D D E L E Y}

Within the framework of this great organisation each individual company operates as a completely separate entity, controlling its own affairs entirely_but by pooling its experience and resources, each company has behind it the combined strength of the Group - unmatched facilities for design, research and production.

\section{LEADER S O FA N INDUSTRY}

ARMSTRONG SIDDELEY MOTORS LTD

SIR W. G. ARMSTRONG WHITWORTH AIRCRAFT LTD

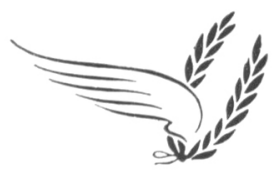

GLOSTER AIRCRAFT CO. LTD • A. W. HAWKSLEY LTD

HAWKER AIRCRAFT LTD • HIGH DUTY ALLOYS LTD

A. V. ROE \& CO. LTD • A. V. ROE CANADA LTD

AIR SERVICE TRAINING LTD

The Hawker Siddeley Group Ltd. 18 St. James's Square, S.W.1. Telephone: Whitehall 2064. 


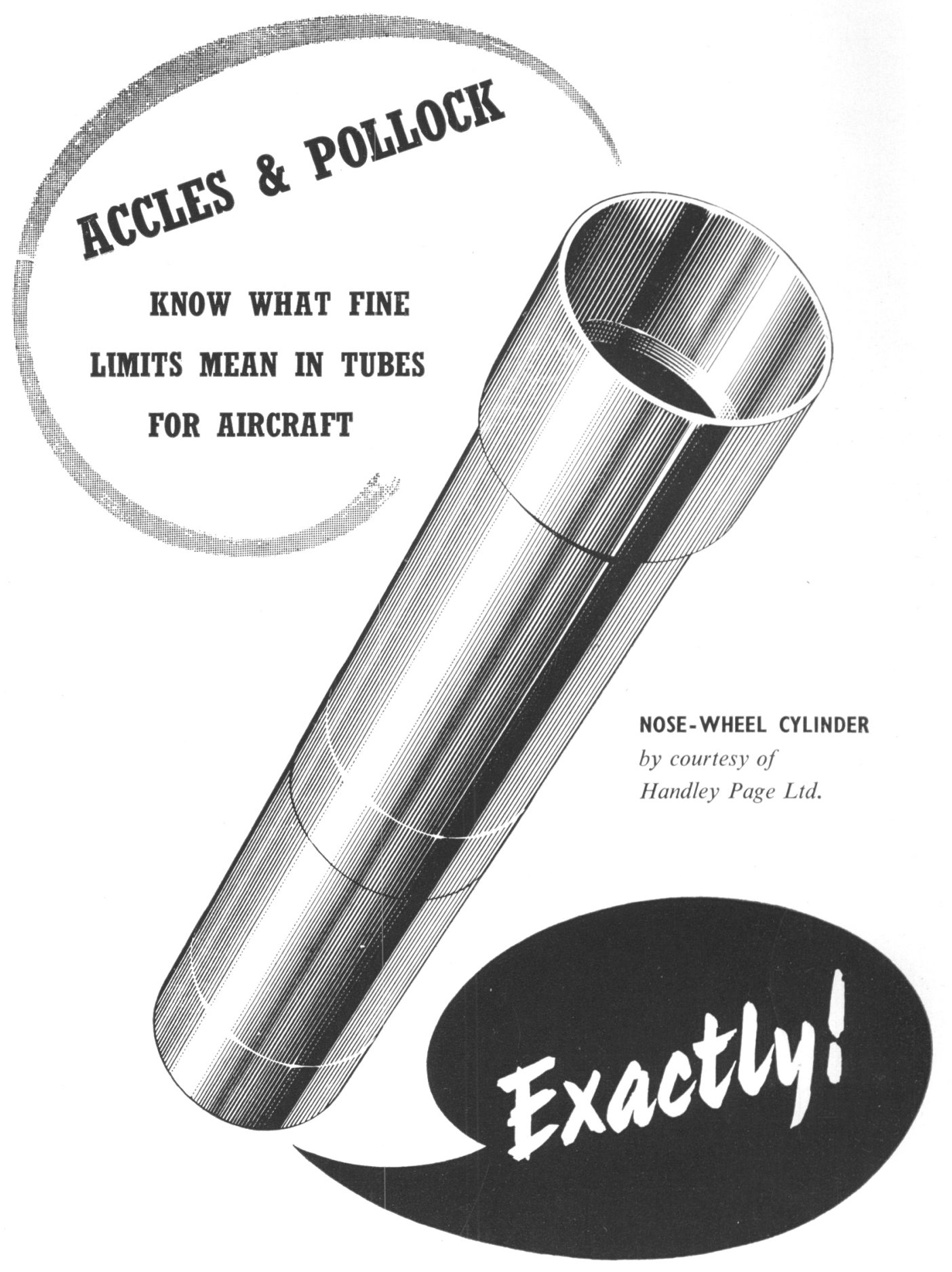

ACCLES \& POLLOCK LTD · OLDBURY · BIRMINGHAM

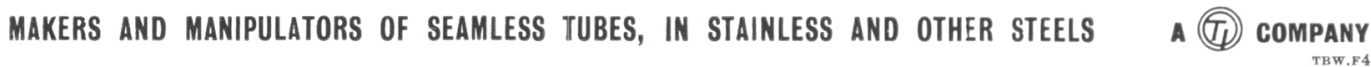




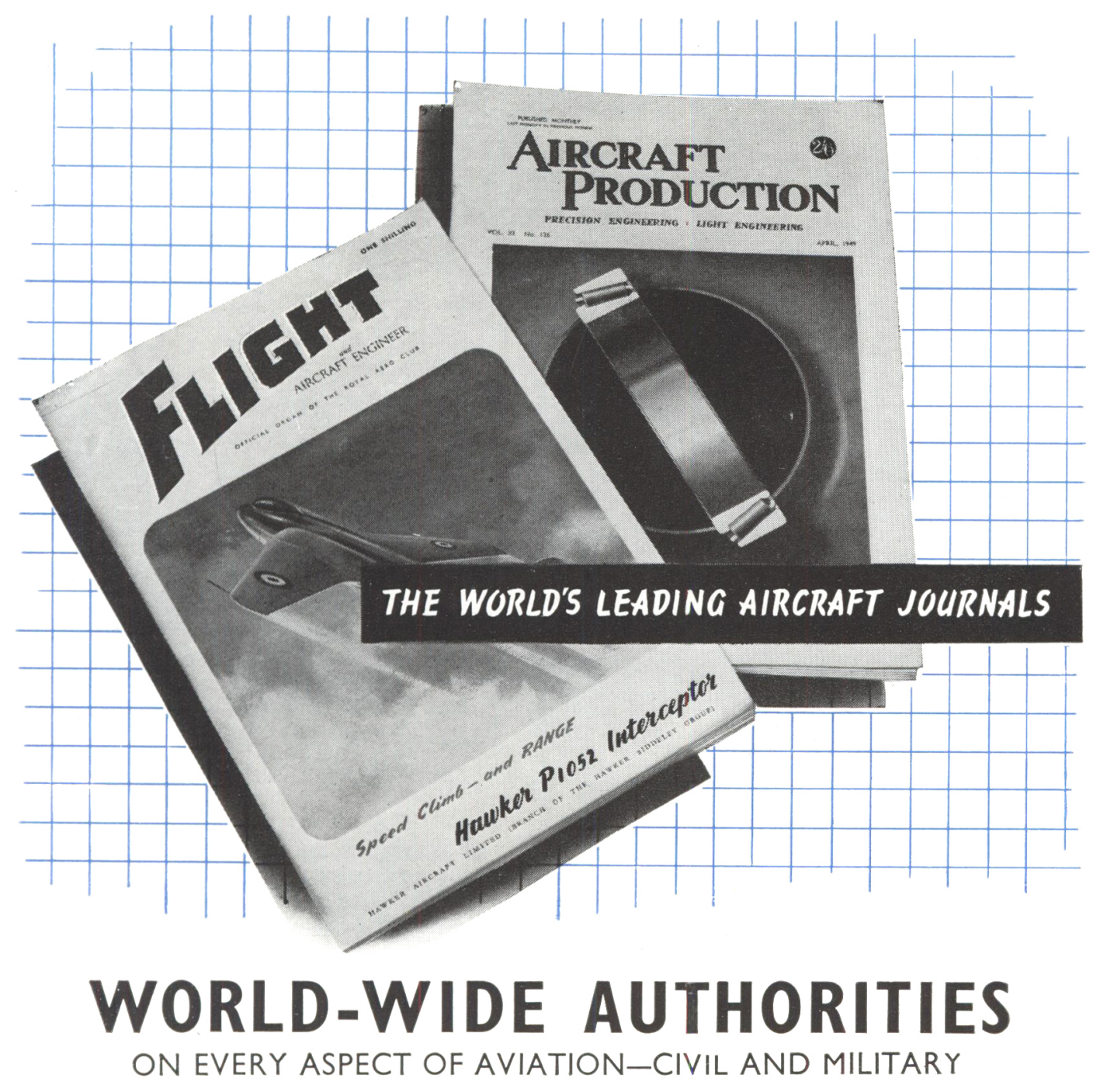

FL I G H Aviation's branches are today so numerous that the specialist who has to keep fully in touch with other people's progress must have up-to-the-minute information on every phase of technical research, development, equipment and operation. He will find it each week in FLIGHT - reliable, critically annotated and well illustrated news of the world's military, commercial and private aviation activities. Thursdays $1 \mathrm{~s}$.

Annual subscription $\notin 31 \mathrm{~s}$.

\section{AIRCRAFT PRODUCTION}

In aircraft manufacture, as in design, the demands made upon the engineer are severe and often unprecedented. Continuous development of production methods is needed and an intimate knowledge of what is required is essential. Such knowledge can be obtained from the detailed practical articles published regularly in AIRCRAFT PRODUCTION, the only specialist journal in its field.

$$
\text { Monthly 2s. 6d. }
$$

Annual subscription $\notin 113 \mathrm{~s}$.

ILIFFE AND SONS LIMITED, DORSET HOUSE, STAMFORD STREET, LONDON, S.E.1 


\section{Air Systems for Aircraft}

By C. A. H. Pollitt, M.I.E.D.. A.M.I.Ae.S. A detailed guide to modern pneumatic equipment used in operating ancillary services in civil and military aircraft. With 95 illustrations, including two folding insets. $25 /$ - net.

\section{Refuelling in Flight}

By C. H. Latimer-Needham, M.Sc.(Eng.)Lond., F.R.Ae.S., M.S.A.E., Chief Engineer, Flight Refuelling Ltd. Foreword by Sir Alan Cobham, K.B.E. Combines a brief history of research and development with a description of the operating techniques employed and an analysis of the economics of flight refuelling. 118 illustrations, $12 / 6$ net.

\section{The Performance of Civil Aircraft}

By F. B. Baker, M.A., A.F.R.Ae.S. An up-to-date guide for civil pilots and aircrews. It includes important information on the characteristics of gas turbines and developments in highaltitude flying. 109 illustrations. 35/- net.

\section{The Practical Engineer \\ Pocket Book, 1951}

Edited by N. P. W. Moore, B.Sc., A.C.G.I., D.I.C A.M.Inst. F, A famous pocket book containing technical data, up-to-date articles on practical aspects of engineering, mathematical tables and formulae, and Technical Dictionaries in German. French and Spanish. Over 750 pages, with numerous illustrations. $8 / 6$ net.

PITuAN. Parker Street, Kingsnay, London, W.C.2.

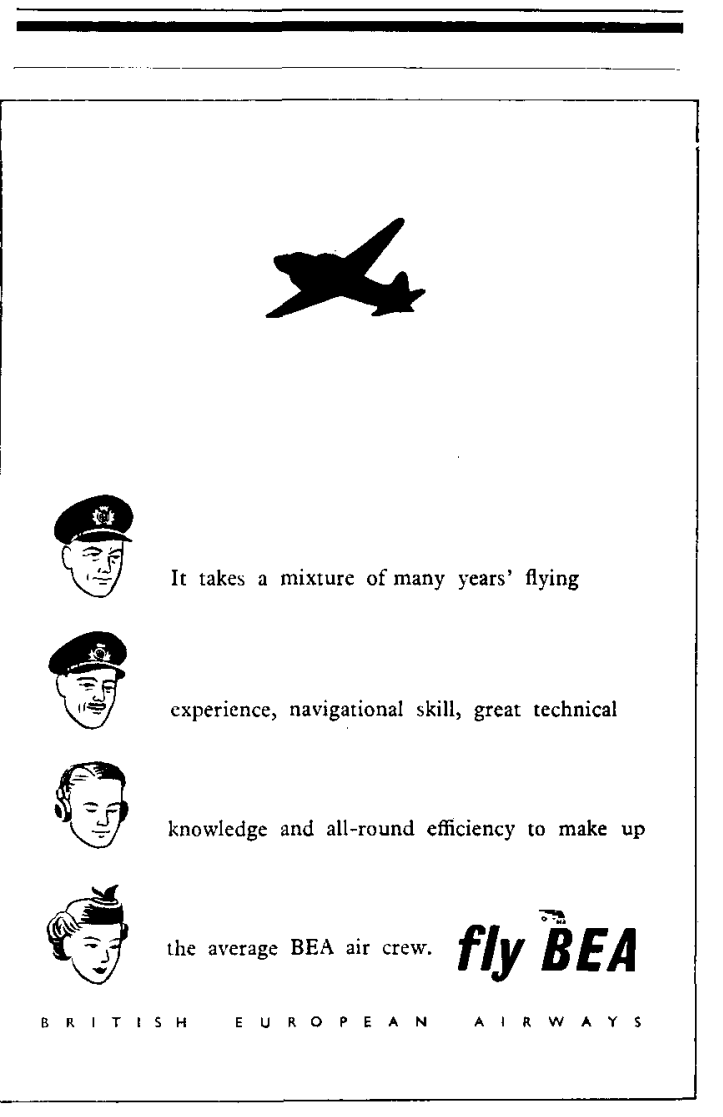

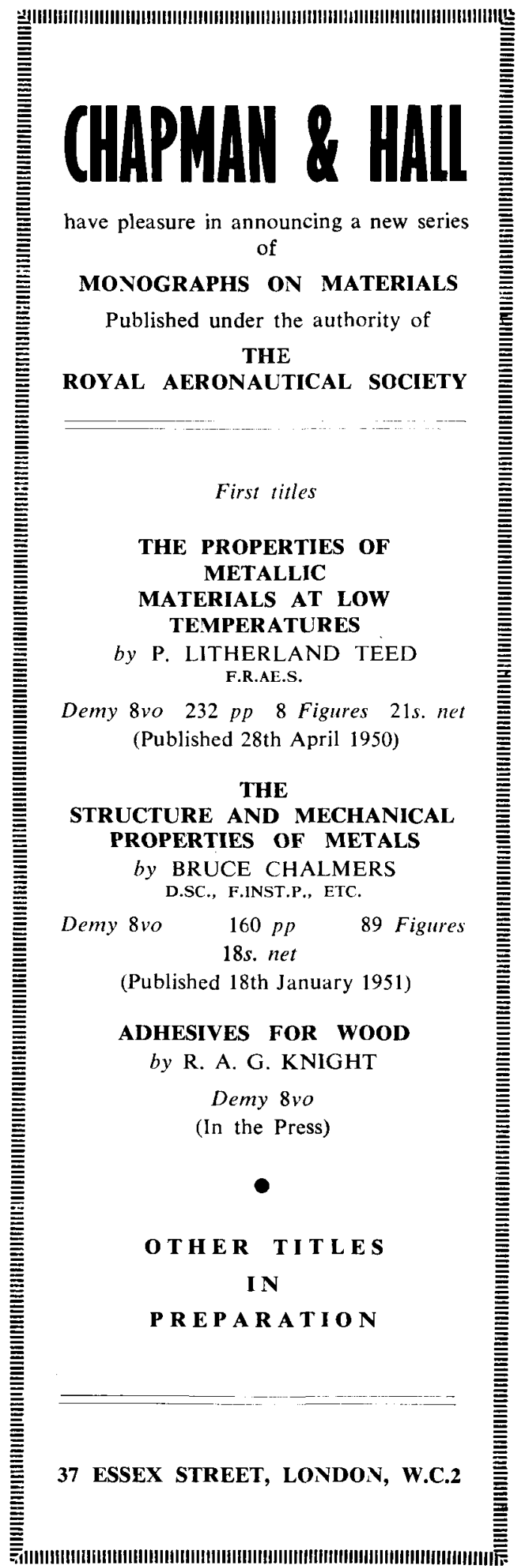


The successful operation of any civil aircraft depends largely on its capacity for further development. The Ambassador will enter airline service with a payload range performance which, good though this is, by no means represents its ultimate possibilities in either piston-engine or turbine form

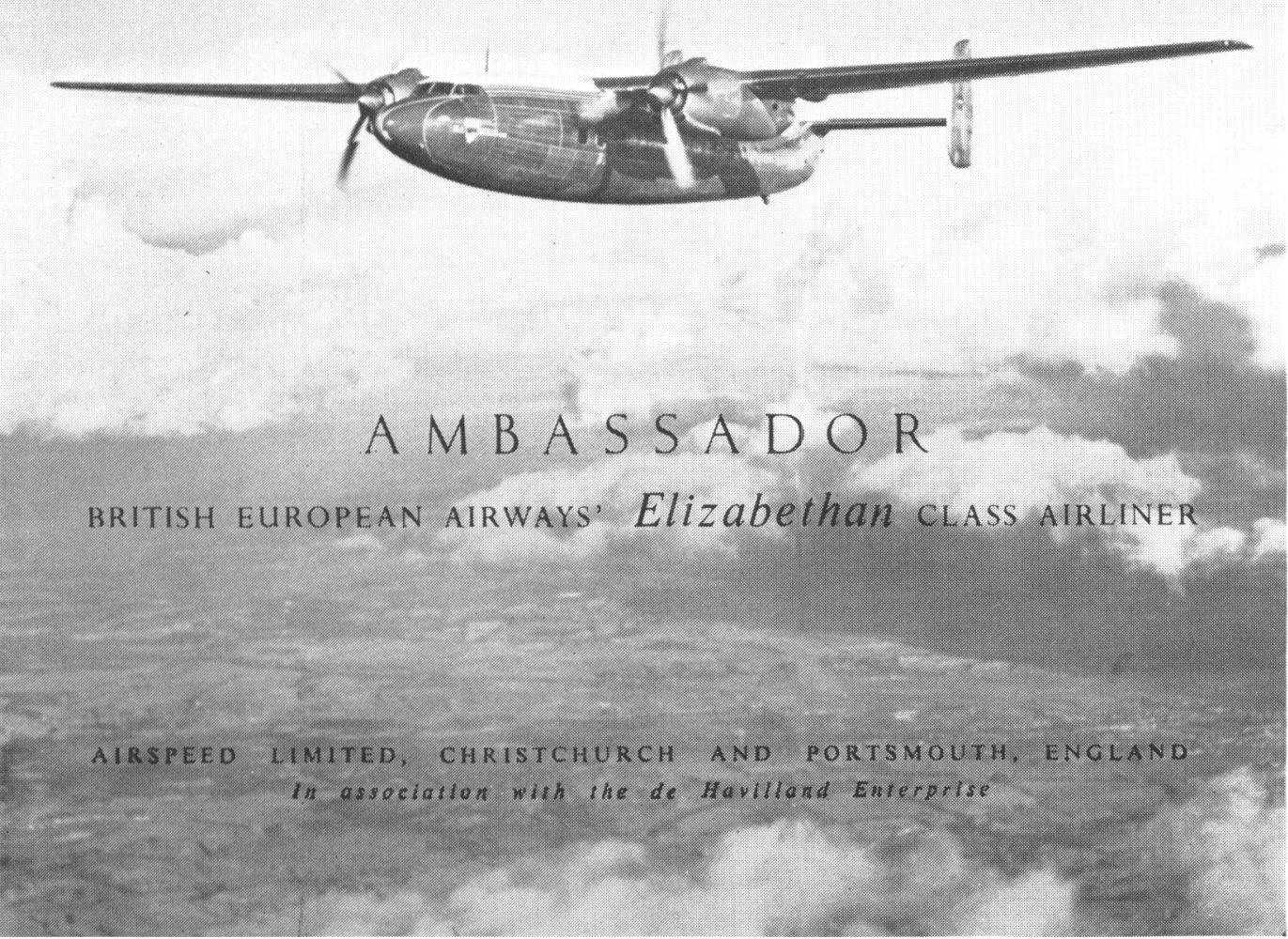




\section{The Vickers Viscount}

\section{- a traveller's joy}

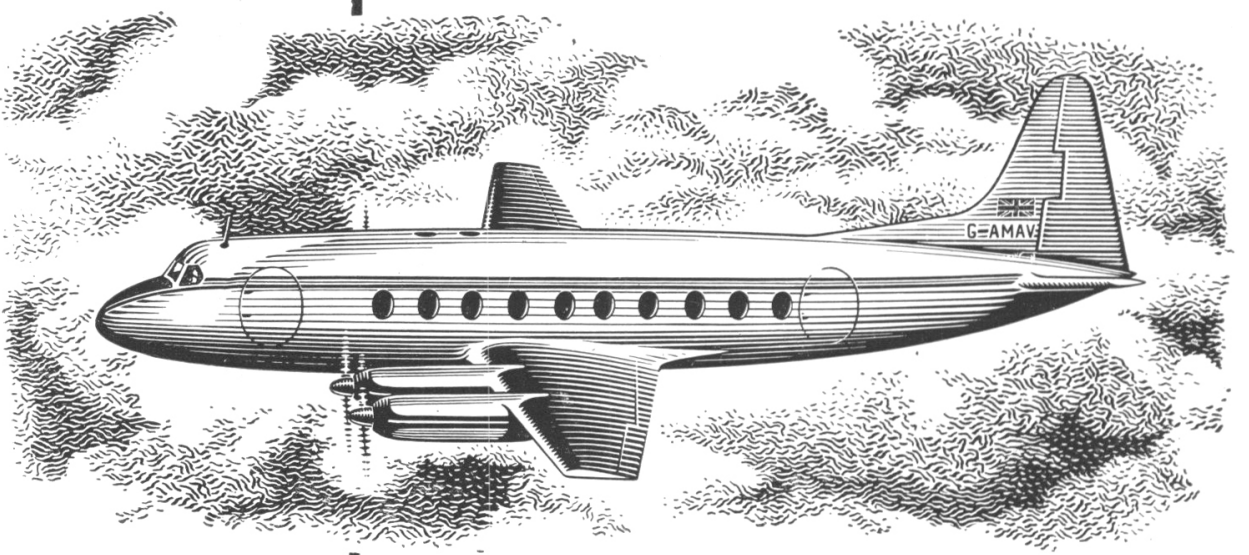

Speeding at 300 m.p.h. at a height of $25,000 \mathrm{ft}$. with no sensation of movement, free from vibration and noise, the traveller flying in the Viscount knows a new standard of airborne comfort. Turbine-driven propellers, cabin pressurization and air conditioning are part of the secret of this new era of air travel. Luxurious seating and extra large oval windows add to the pleasure of flying by Viscount.

\section{THE VICKERS VISCOUNT}

Powered by four Rolls-Royce Dart Propeller-Turbine engines.
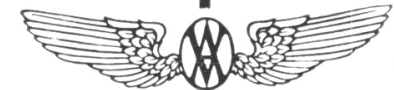

VI CKERS - A R M S TR ONGS L IM I TED
A I R C R A F T
D I V I S I O N
W E Y B R I D G E
S U R R E Y 

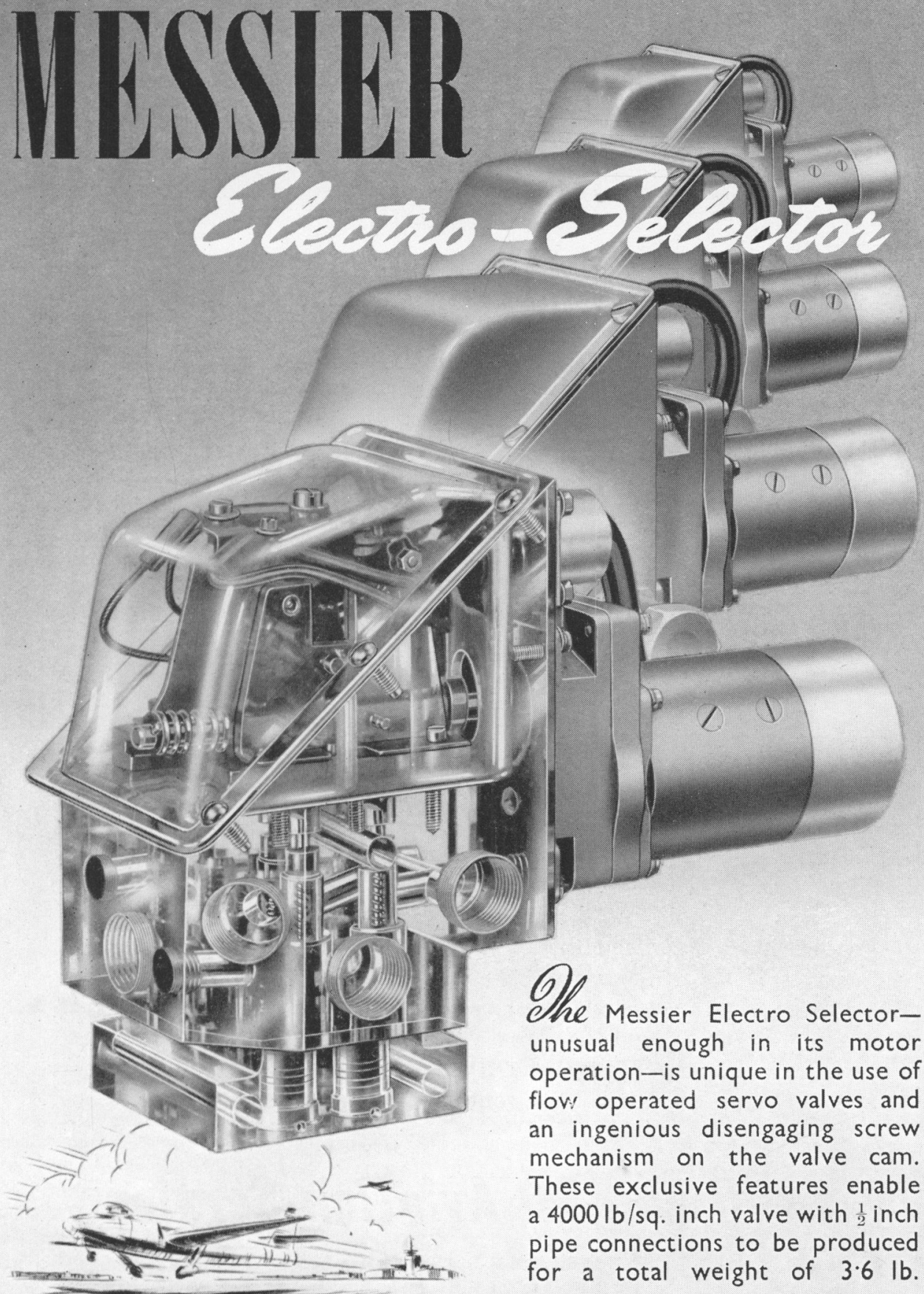

\section{BRITISH MESSIER LTD . GLOUCESTER}




\section{Do you know your airfields?}

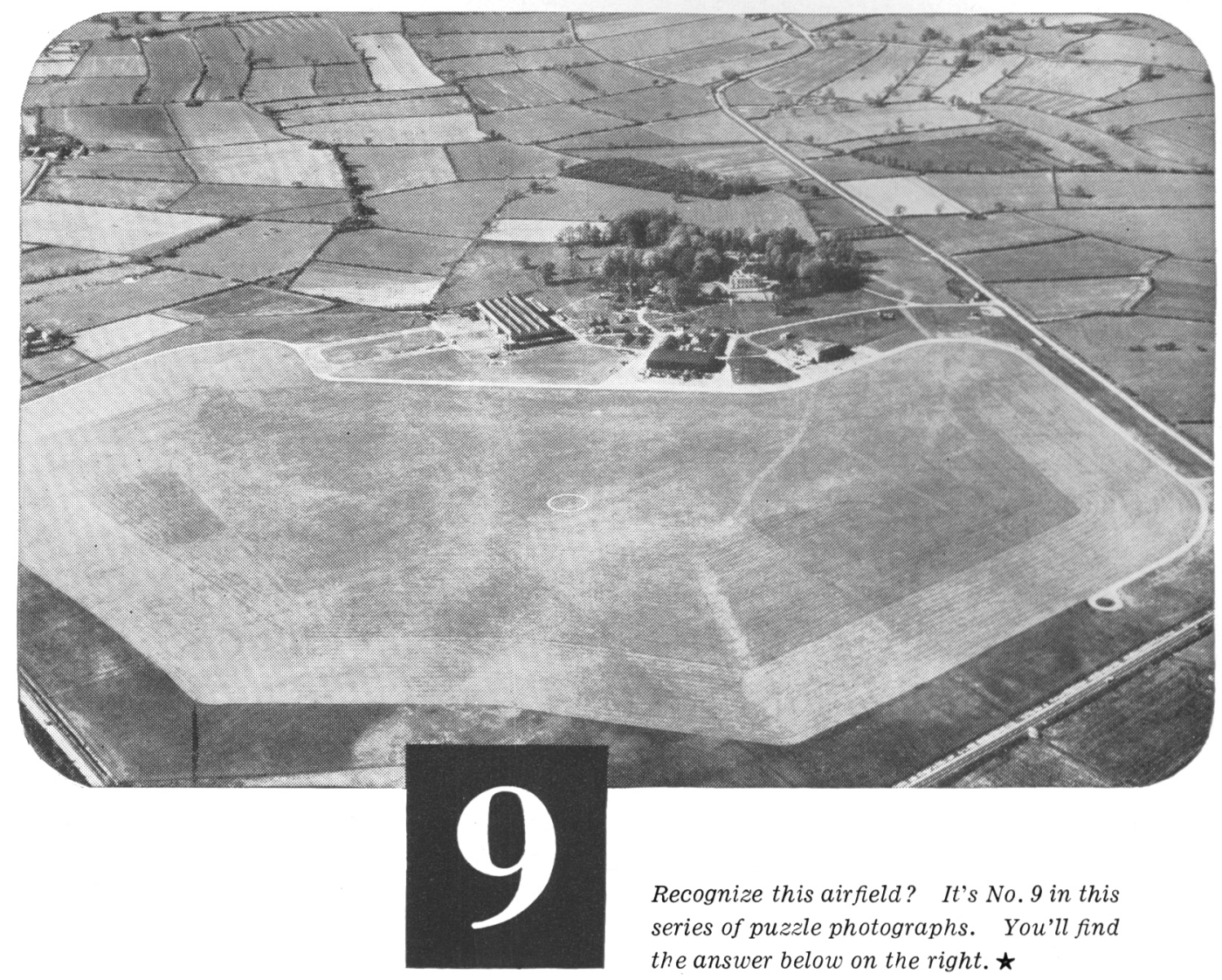

The pilots of twenty-three international airlines, of numerous charter companies and flying clubs, all appreciate the swift, cheerful service given by Shell and BP crews. The Aircraft Servicing Vehicles of the Shell and BP Aviation Service are on duty all year round at twenty-five aerodromes throughout the country.

\section{Shell and BP Aviation Service}

Shell-Mex and B.P. Ltd., Shell-Mex House, Strand, W.C.2. Distributors in the U.K. for the Shell and Anglo-Iranian Oil Groups. 


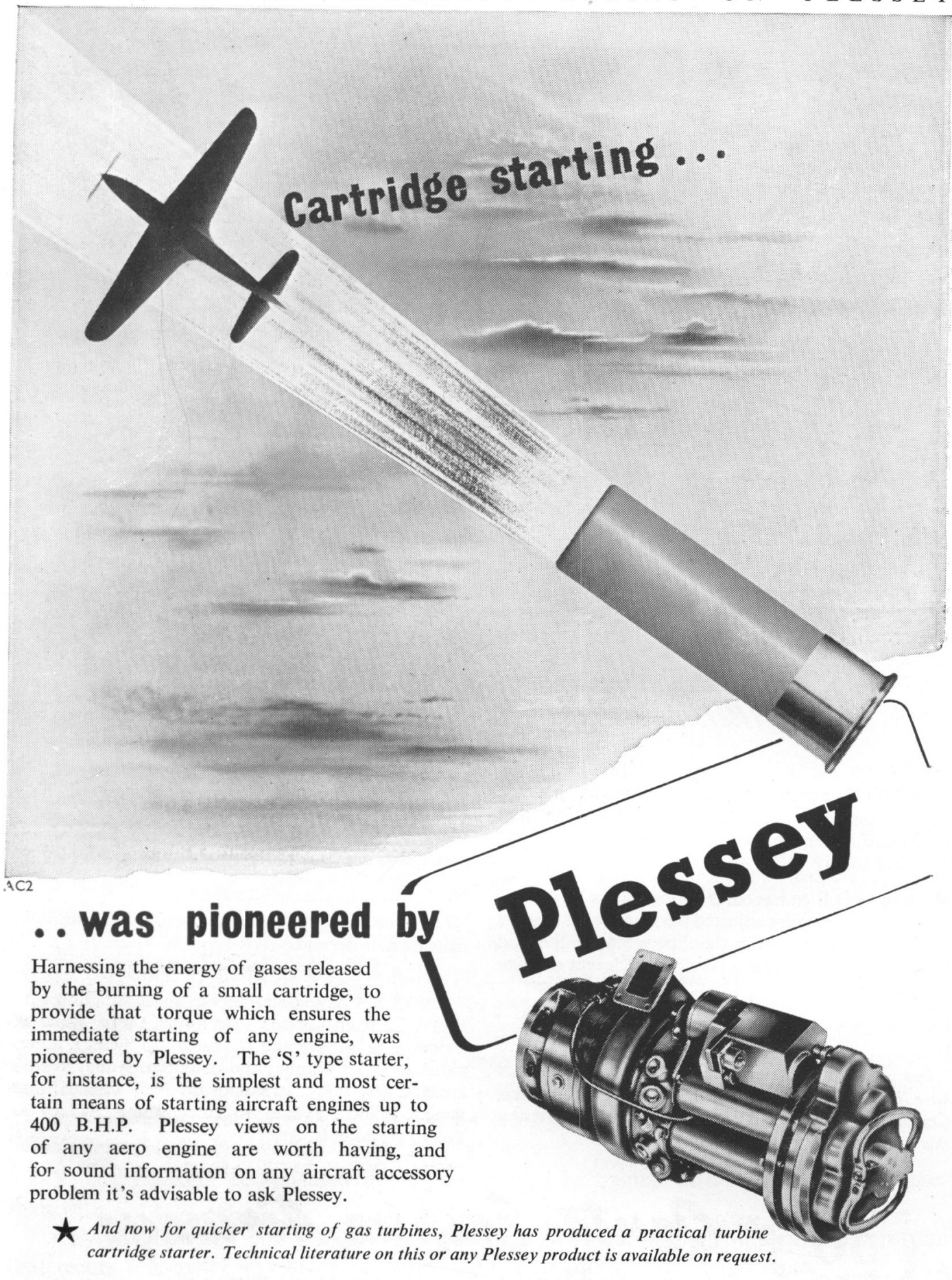

PUMPS - VALVES - CARTRIDGE STARTERS - 'BREEZE' WIRING SYSTEMS - ELECTRIC ACTUATORS - RADIO COMMUNICATIONS

T H E

P L E S S E Y

C O M P A N Y

L I M I T E D

I L F O R D

E S S E X 


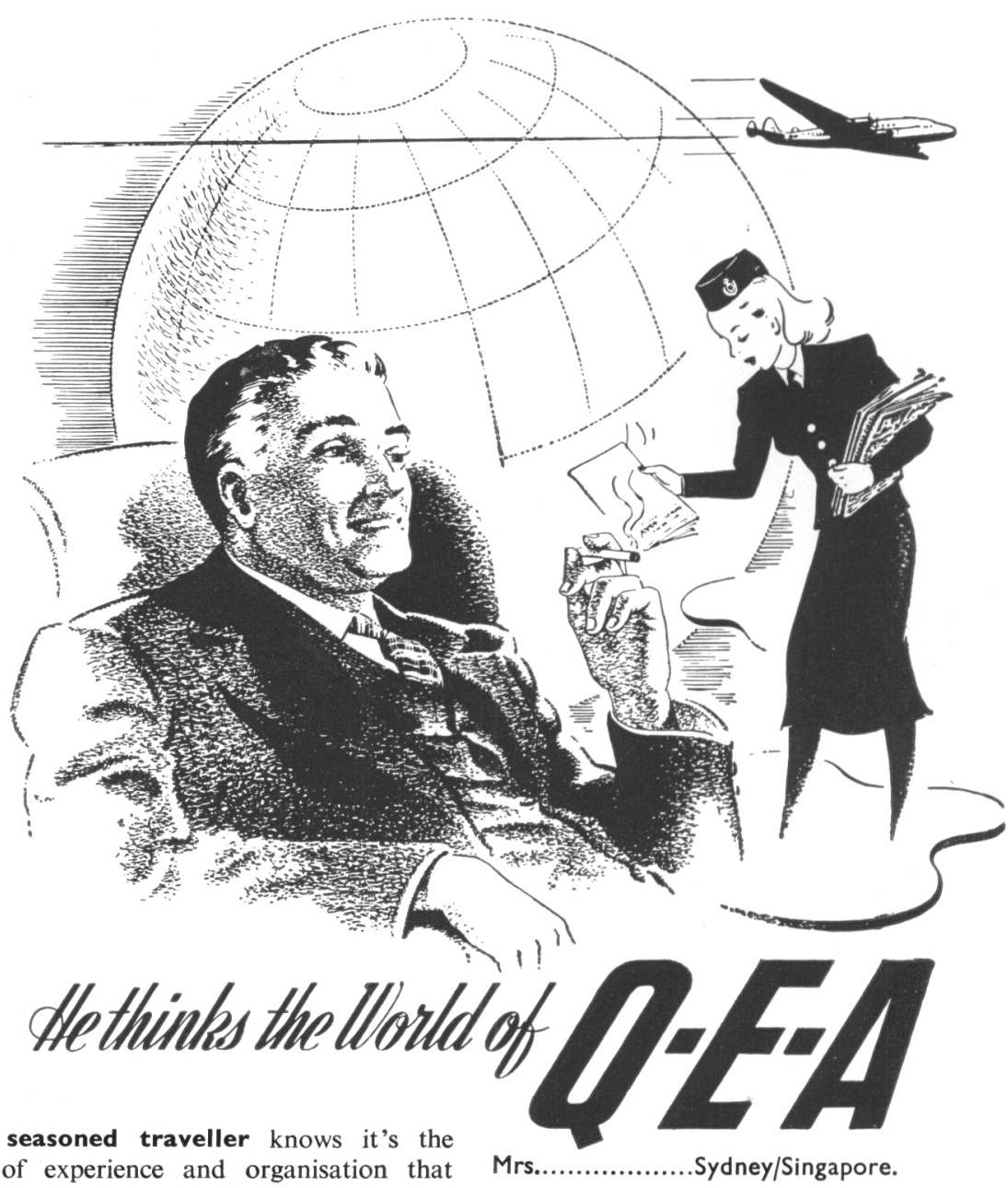

TO-DAY'S seasoned traveller knows it's the combination of experience and organisation that makes Q.E.A. service the world's best in the air transport field to-day.

He knows Q.E.A. has come a long way in 30 yearsfrom the time the pilot adjusted the passenger's goggles and heavy leather coat to the time when the Steward or Air Hostess provides a service that leaves nothing to be desired.

\section{Here's what Q.E.A. passengers say-} Mr...................London/Sydney.

-During the period since the cessation of hostilities I have travelled by air to South America, North America, Canada, Africa and parts of Europe, and without reserve this has been the most satisfactory passage."

Mrs.

Sydney/Singapore.

"The many attentions of the excellent Steward and Stewardess are so much appreciated."

Mr................... Karachi/London.

" The Constellation is the most comfortable of the many planes I have been in.",

$$
\text { (Original letters on file) }
$$

Fly by Q.E.A. Kangaroo Service (in association with B.O.A.C.) from London-via Rome, Cairo, Karachi, Calcutta, Singapore and Djakarta-to Sydney. Alternative route via Bombay and Colombo. Sydney to New Zealand (By TEAL). Sydney to New Guinea, and Pacific Islands. Sydney to Hong Kong. Sydney to Tokyo via Manila.
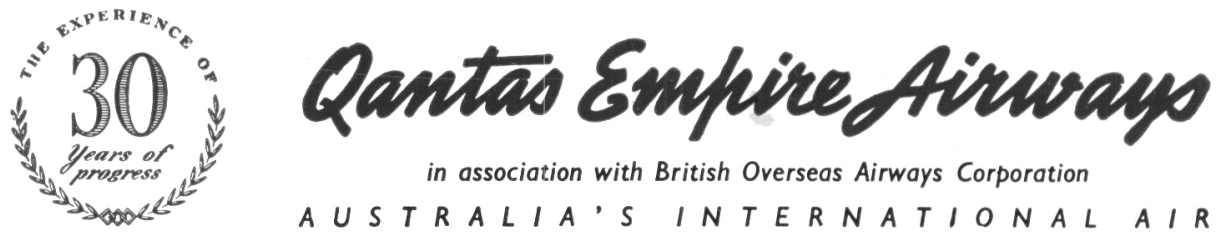

in association with British Overseas Airways Corporation

A U S TRALIA'S INTERNATIONALAIRLINE 


\section{THE ROYAL AERONAUTICAL SOCIETY PAPERS FOR THE JOURNAL}

The Council have set aside an annual sum of $£ 250$ for the award of premiums for papers published in the Journal. Both members and non-members are invited to contribute original papers on their own special subjects. The following notes on the preparation of papers for the JOURNAL are given to assist contributors:-

\section{COPYRIGHT}

The copyright of every paper printed in the JOURNAL shall be the property of The Royal Aeronautical Society. If the author makes use of copyright material in his paper or information obtained by reason of his employment or otherwise, he must state clearly in his covering letter, or in the paper, that consent has been given for the use of such material.

\section{MANUSCRIPTS}

Papers must be in English, in the third person, and typed on one side of the paper only, with double spacing and wide margins. When submitted they must be in their final form for publication. Only typographical errors may be corrected in proofs. Titles of papers should be brief.

Where practicable, a summary of not more than 250 words should be given at the beginning of the paper, giving its scope and conclusions.

All references should be numbered in the text where they occur, and the complete list of references given at the end of the manuscript. These references will be published at the end of the text. Footnotes should be numbered consecutively. Tables should be kept as concise as possible.

\section{ILLUSTRATIONS}

Illustrations must be drawn so that they will reduce to column or two-column width, that is to $2 \frac{5}{8}$ or $5 \frac{1}{2}$ inches. Full page illustrations must reduce to $5 \frac{1}{2}$ inches by 8 inches. All drawings must be in black ink on white paper or tracing cloth.

Lettering and figures on drawings must be in pencil only. Drawings should be posted flat or rolled.

Photographs should not be less than half plate in size and must be clear black and white glossy prints.

Every drawing and photograph should have on its back its figure number and title.

\section{MATHEMATICS}

Only very simple symbols and formulæ should be typewritten. All others should be written carefully by hand in ink. Ample space for marking should be allowed above and below all equations. Greek letters should be designated by name in the margin.

The difference between capital and lower-case letters should be clearly shown; care should be taken to avoid confusion between zero $(0)$ and the letter o, between the numeral one (1) and the letter l, between alpha and a, kappa and $\mathrm{k}, \mathrm{mu}$ and $\mathrm{u}$, nu and v, eta and $\mathrm{n}$.

All subscripts and exponents should be clearly marked, and dots, bars, and so on, over letters should be avoided as far as possible.

Square roots of complicated expressions should be written with the exponent $\frac{1}{2}$ rather than with the sign $\sqrt{ }$.

Complicated exponents and subscripts should be avoided. Any complicated expression that recurs frequently should be represented by a special symbol.

Unless an abbreviation is one recognised as standard practice, both in this and other English-speaking countries, for example b.h.p. for brake horse power, the meaning should be given in full on its first use. 


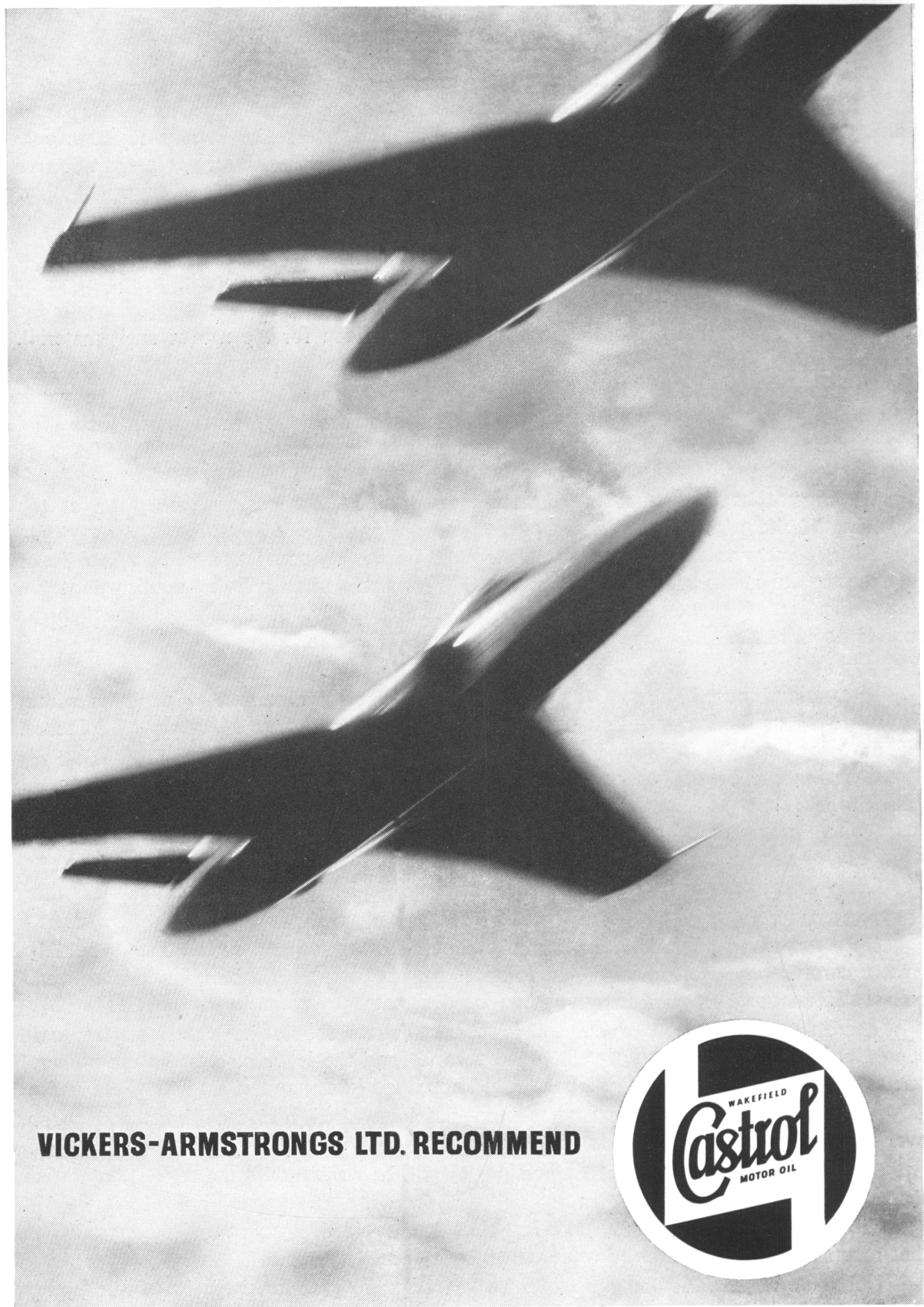




\section{THE SOCIETY'S AWARDS}

The Society offers a number of valuable awards, most of them annually. Full particulars of the conditions attaching to these awards may be obtained on application to the Secretary.

\section{Society's Gold Medal}

The highest honour which the Society can confer for work of an outstanding nature in aeronautics.

\section{Society's Silver Medal}

Awarded for work of an outstanding nature in aeronautics.

\section{Society's Bronze Medal}

Awarded for work leading to advance in aeronautics.

\section{British Gold Medal for Practical Achieve- ment in Aeronautics}

Awarded for outstanding practical achievement leading to advancement in aeronautics.

\section{British Silver Medal for Practical Achieve- ment in Aeronautics}

Awarded for practical achievement leading to advancement in aeronautics.

\section{Wakefield Gold Medal}

Awarded annually, at the discretion of the Council, to the designer or inventor of any apparatus tending towards safety in flying.

\section{The George Taylor (of Australia) Gold Medal}

Awarded annually, at the discretion of the Council, for the most valuable paper read during the previous session.

\section{Simms Gold Medal}

Awarded annually, at the discretion of the Council, for the most valuable contribution read before, or received by, the Society on any subject allied to aeronautics, e.g. structures, meteorology, metrology, etc.

\section{Herbert Akroyd Stuart Memorial Prize}

Awarded at the discretion of the Council for the most valuable contribution read before, or received by, the Society on applied thermodynamics.

\section{Edward Busk Memorial Prize}

Awarded annually, at the discretion of the Council, for the most valuable contribution read before, or received by, the Society on applied aerodynamics.

\section{Orville Wright Prize}

Offered annually for the best contribution on some subject of a technical nature in connection with aeronautics, which is received by the Society and published in The Aeronautical Quarterly.

\section{Pilcher Memorial Prize}

Awarded annually, at the discretion of the Council, for the most valuable paper read by a Graduate or Student during the previous year at any meeting of the Society or its Branches.

\section{Usborne Prize}

Awarded annually, at the discretion of the Council, for the best contribution to the Society's publications written by a Graduate or Student on some subject of a technical nature in connection with aeronautics.

\section{R. P. Alston Memorial Prize}

Awarded for practical achievement associated with the flight testing of aircraft.

\section{Major Baden-Powell Memorial Prize}

Awarded to the best entrant in the Associate Fellowship Examination.

\section{Wilbur Wright Memorial Premium}

The Wilbur Wright Memorial Lecture is held annually, a premium of $£ 75$ being awarded to the lecturer, if British, or $£ 125$ if he is an American, invited by the Council to deliver the lecture. The lecture is usually given alternately by an American and an Englishman, and is the most important aeronautical lecture of the year.

\section{British Commonwealth and Empire Lecture}

The British Commonwealth and Empire Lecture is delivered annually by a lecturer chosen in alternate years from the British Dominions and Colonies and Great Britain.

The British Commonwealth and Empire Lecture has a premium of $£ 50$ and in the case of lecturers from the Dominions and Colonies an allowance is paid towards the lecturer's expenses.

\section{Branch Prize}

The Council offer an annual prize of twenty guineas for the best paper read before the Branches during the previous lecture session. The prize is open to any member of the Society or of any Branch. 


\section{When its a question of \\ PNEUMATIC OPERATION : \\ D U N L O P \\ has the answer}

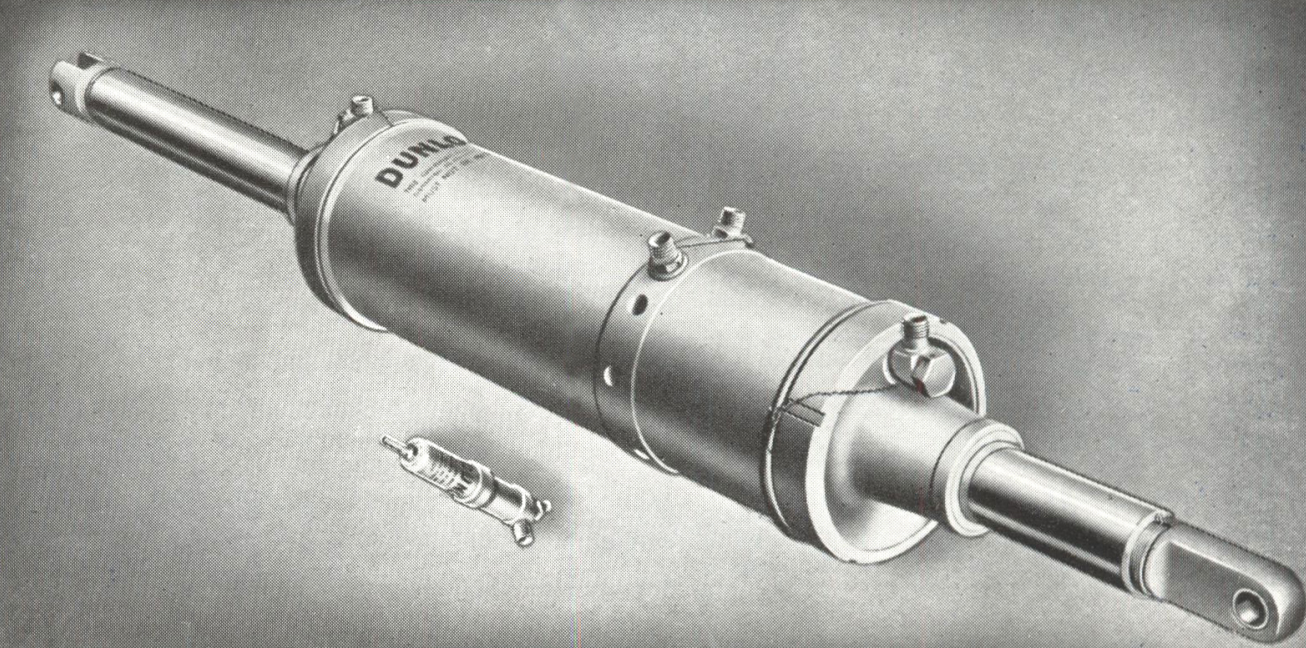

Maximum efficiency in the operation of flaps, doors, turrets, undercarriage and other components calls for special attention to Jack design. Dunlop Pneumatic Jacks have been developed by technicians of great experience. A unique self-aligning piston head assures low friction value. Gland design ensures that the Jacks are leak-proof

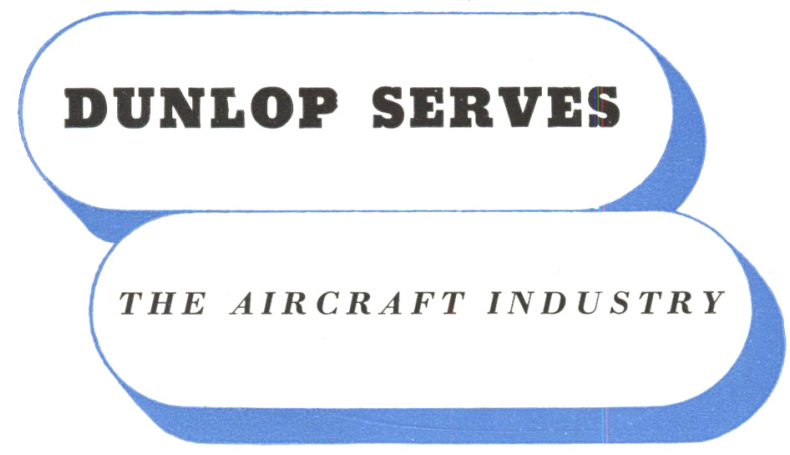
from $-50 \mathrm{C}^{\circ}$ up to $+90^{\circ} \mathrm{C}$. Dunlop Jacks are standard equipment on Avro 'Athena', Boulton Paul 'Balliol', and De Havilland 'Dove' and are also used on Rolls-Royce power plants. Special Jacks can be designed to specific requirements. On Jacks, or any other problem of pneumatic actuation, Dunlop tech. nicians are always at the service of designers and constructors.

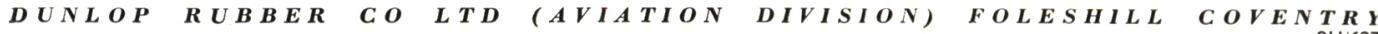

